Fanum

Sociológico

\section{Forum Sociológico}

Série II

35 | 2019

Arte urbana: Contextos, tendências e desafios

\title{
Os gestos da arte urbana: por uma etnografia das gestualidades
}

The gestures of urban art: for an etnography of gestuality

José Luís Abalos Júnior

\section{(2) OpenEdition \\ Journals}

Edição electrónica

URL: https://journals.openedition.org/sociologico/7979

DOI: 10.4000/sociologico.7979

ISSN: 2182-7427

Editora

CICS.NOVA - Centro Interdisciplinar de Ciências Sociais da Universidade Nova de Lisboa

\section{Edição impressa}

Paginação: 19-29

ISSN: 0872-8380

Refêrencia eletrónica

José Luís Abalos Júnior, «Os gestos da arte urbana: por uma etnografia das gestualidades», Forum Sociológico [Online], 35 | 2019, posto online no dia 11 dezembro 2019, consultado o 29 março 2022 URL: http://journals.openedition.org/sociologico/7979; DOI: https://doi.org/10.4000/sociologico.7979 


\title{
OS GESTOS DA ARTE URBANA: POR UMA ETNOGRAFIA DAS GESTUALIDADES \\ THE GESTURES OF URBAN ART: FOR AN ETNOGRAPHY OF GESTUALITY
}

\author{
José Luís Abalos Júnior \\ Universidade Federal do Rio Grande do Sul (UFRGS) / Instituto de Filosofia e Ciências Humanas (IFCH) / Programa de \\ Pós-Graduação em Antropologia Social (PPGAS)
}

\begin{abstract}
Resumo
Tags. Graffiti. Sticker art. Stencil. Nos últimos anos temos percebido um aumento tanto destas formas de expressão visual na cidade, quanto em pesquisas acadêmicas que buscam entendê-las. Ao pensar a arte urbana além de sua estética final, proponho que há outros elementos envolvidos no processo artístico de quem intervém nas ruas. Os "gestos da arte urbana" vão desde um momento inicial no qual artistas imaginam suas expressões até a divulgação digital das obras. Uma etnografia que dê conta destes processos precisa ter uma educação atenta às gestualidades representadas em mãos performáticas, em sons, na relação do sujeito com a estrutura em que intervém, etc. Trazendo referências teóricas que pensam o gesto, recorro a autores que abordam uma fenomenologia da experiência e uma ontologia política dos gestos. Concluo refletindo sobre o gesto na arte urbana e como este opera como uma "partilha do sensível": dimensão artística, estética e política de expressões visuais na cidade.
\end{abstract}

Palavras-chave: rua, expressões urbanas, graffiti, etnografia

\begin{abstract}
Tags. Graffiti. Sticker art. Stencil. In the last years we have noticed a raise, both in these forms of visual expression in the city as in academic research that seeks to understand them. By thinking urban art beyond its final aesthetic, I propose that there are other elements involved in the artistic process of those who intervene in the streets. The "gestures of urban art" go beyond an initial moment in which artists imagine their expressions, until the digital dissemination of their works. An etnography that handles this processes needs to have a careful education attented to the gestualities represented in performatic hands, in sounds, and in the relation between the subject and the structure in which he interveins, etc. Bringing theoretical references that explore the gesture, I resort authors that address a phenomenology of experience and a political ontology of gestures. I conclude by reflecting on the gesture in urban art and how it operates as a "sharing of the sensible": artistic, aesthetical and political dimension of visual expressions in the city.
\end{abstract}

Keywords: street, urban expressions, graffiti, ethnography

A observação participante convida o antropólogo noviço a se manter atento ao quuijke os outros estão fazendo e dizendo, ao que acontece a sua volta; a acompanhar os demais onde quer eles vão ficar à sua disposição, não importando o que isso implique e para onde leve. Fazê-lo pode ser perturbador e implicar riscos existenciais consideráveis.

Ingold, 2016, p. 408

Há alguns anos a dona de uma casa com um grande muro, no bairro da Restinga em Porto Ale-
gre/RS, havia permitido que um menino, artista urbano iniciante na arte de rua, pintasse seu muro. Do outro lado da rua havia uma árvore na qual as pessoas sentavam-se à sombra para ver o neófito artista desenvolver seu trabalho com pincel e tinta. No final da tarde a dona de casa trazia café, pão e todo o público curioso perguntava ao menino o que significavam seus desenhos. Essa cena onírica foi-me contada por Jackson Brum, reconhecido artista urbano gaúcho, ao lembrar de histórias da 
sua trajetória pintando nas ruas. Ela nos remete um contexto processual no qual o gesto, enquanto tempo e espaço do processo artístico, associa-se a momentos memoráveis.

Nesse trabalho refletirei sobre intervenções artísticas urbanas através dos seus gestos. Terei como objetivo demonstrar a importância desta dimensão, por vezes não visibilizada em prol de uma análise que foca unicamente na estética final do que vemos estampado nos muros da cidade. O momento dos processos das pinturas, colagens, e qualquer outra modalidade de intervenção urbana, faz parte de um conjunto de etapas pelas quais graffitis, sticker arts, murais, "aparecem" e também merecem uma atenção etnográfica. Logo, a "etnografia das gestualidades" se refere a este acompanhamento atento do etnógrafo que tem em artistas urbanos o centro do seu trabalho de campo na cidade.

Mas o que é um gesto? Ao pensarmos intervenções artísticas urbanas como manifestações sociais, fenômeno da cidade contemporânea, é evidente o papel que a figuração toma na sociedade moderna. Em grandes metrópoles somos rodeados por expressões visuais, formas pictóricas que nos chegam através do sentido da visão. Esse processo denota uma "proeminência do comportamento figurativo", como coloca Leroi-Gourhan no clássico O Gesto e a Palavra (2002). É sobre este gesto, muitas vezes deixado de lado em prol de uma análise unicamente estética de intervenções urbanas, que este texto se propõe refletir.

Contudo, é Giorgio Agamben o autor que mais se preocupa em responder a esta questão. No recentemente traduzido Por uma ontologia e uma política do gesto (2018), o autor italiano reflete sobre as dificuldades de delimitar este conceito e sobre as possibilidades de uma historização dos gestos na história da humanidade. Gesto, na sua etimologia, vem do latim gestus, que pode significar "qualquer atitude do corpo de uma pessoa"1.

É ao falar dos gestos de artistas urbanos que encontramos o tema do espaço e do tempo. Ricardo Campos (2010) reflete sobre as relações entre o espaço/tempo no graffiti e reflete que podemos ver o espaço de maneira macroscópica e microscópica. Já o tempo, algo menos evidente nas pesquisas sobre o tema, pode ser visto de forma histórica ou experiencial. Isso é importante de ser referido pois é através da gestualidade, implicada na criatividade artística, que as dimensões do espaço e do tempo são articuladas.

Há uma distinção tênue entre categorias e conceitos como graffiti, street art, pós-graffiti, arte urbana, etc. O reconhecimento das diferenças que envolvem cada modelo de intervenção urbana se refere a uma variedade de usos do espaço/tempo e dos gestos performatizados por artistas urbanos. Segundo Ricardo Campos (2010), na trajetória his- tórica, o graffiti desenvolveu-se, de um lado, em manifestações visuais relacionadas a assinaturas e tags, que são códigos visuais de difícil entendimento para quem não participa deste contexto cultural. E, por outro lado, o graffiti desenrolou-se em manifestações pictóricas, ligadas à criação de personagens, com maior necessidade de tempo e técnica para produção, e maior aceitabilidade social. Esse aperfeiçoamento do graffiti clássico reflete uma "estetização" que levou a criação de outros conceitos como "street art" e "arte urbana".

Portanto, nesse texto abordo o tema do espaço microscópico que aponta para uma relação entre artistas e seus espaços de intervenção e as ferramentas utilizadas para produção do ato artístico na cidade. No que se refere ao tempo, faço uma análise do tempo experiencial, que envolve as gestualidades de quem se aventura a expressar-se na rua. Para falar dos gestos que ocorrem na cidade, tenho a "etnografia de rua" (Eckert \& Rocha, 2013) como opção metodológica, pois ela leva o antropólogo urbano, através da presença física nas ruas da cidade, a uma aproximação ontológica dos habitantes da urbe. Uma etnografia das gestualidades diz respeito a um olhar aproximado e atento às dinâmicas espaciotemporais de artistas urbanos. Como reflete Ricardo Campos,

Os graffiti-writers conhecem bem a materialidade urbana e para a execução da sua pintura precisam, claramente, de incorporá-la. Necessitam de saltar muros, subir ou pendurar-se em andaimes, descer ao subsolo. Precisam de conhecer as diferentes superfícies e a reacção às tintas no cimento, no tijolo ou no metal. Há um domínio do território e da sua materialidade que é fator crucial de sucesso.

Campos, 2017a, p. 9

Metodologicamente, trabalho com a "etnografia de rua", que diz respeito a acompanhamento de "experiências e prática cotidianas que o etnógrafo urbano compartilha em sua observação do outro que se desloca na cidade" (Eckert \& Rocha, 2013, p. 22). Ao caminhar com artistas urbanos na cidade de Porto Alegre, busquei uma aproximação dos seus gestos. A presença no instante das intervenções deu-me acesso a um "mundo gestual" realizado por personagens urbanos que intervêm na urbe. Em sua maioria, os sujeitos com quem conversei eram homens, negros, advindos de classe popular e nascidos nas periferias da cidade ${ }^{2}$.

Outra ferramenta desta pesquisa é a de entrevistas semidiretivas nas quais utilizo um roteiro preliminar que envolve questões como a de trajetórias individuais, projetos de vida, carreiras artísticas, deslocamentos globais e suas implicações culturais e o papel da arte do graffiti nas transformações de grandes centros urbanos. Nestas entrevistas, que muitas vezes ocorrem no próprio ato etnográfico 
enquanto o artista se expressa, objetivei acessar à imaginação, e imaginar junto, percebendo as referências pelas quais artistas urbanos são inspirados.

Uma terceira dimensão metodológica é a etnografia audiovisual, que envolve construção de coleções etnográficas ${ }^{3}$, aqui focada na dimensão fotográfica. A antropologia visual, associada à etnografia da e na cidade (Eckert \& Rocha, 2013), diz respeito a técnicas e ferramentas de percepção antropológica que podem contribuir para o acompanhamento das gestualidades de artistas urbanos. A apresentação dos gestos em narrativas visuais busca contribuir para novas formas de escrita que ultrapassem a dimensão bidimensional do texto escrito.

Dito isto, primeiramente trago o gesto em uma dimensão fenomenológica, suscitada por Gaston Bachelard (1991; 2003) e Leroi-Gourhan (2002), na qual ele é um espaço marcado pela ação imaginante e pelos processos figurativos. Em um segundo momento, reflito sobre gesto a partir das dinâmicas da rítmica e das gerações, trazendo questões como a da tradição e da liberdade nas apropriações técnicas e gestuais, em uma perspectiva ontológica e política proposta por Agamben (2018). Por fim, trago a referência a Tim Ingold (2010; 2012; 2016), para pensar o gesto enquanto um fluxo de vida e um movimento ligado à educação da atenção.

Essas três perspectivas ficam mais ricas quando as associamos com fotografias e desenhos advindos de uma etnografia que vise o acompanhamento de gestualidades de artistas que intervêm na urbe.

\section{O gesto enquanto devaneio da vontade e alvo etnográfico}

A cidade é pintada todos os dias por pequenos gestos. Diminutos, quase invisíveis. Um ato anônimo que deixa evidências. Abelhas, monstros coloridos, letras em bomb ${ }^{4}$ são parte desses fragmentos visíveis. Qual imaginação criadora dá formas a estes seres que compõem a cidade? Buscando responder tal pergunta, conheci "Jota Pê" da mesma forma que sempre o vi: sujo de tinta. Para um artista urbano, a tinta é a marca que sacraliza o gesto. E foi no meio da sujeira das colorações impregnadas nas mãos que partilhamos a experiência com o spray.

Sob um calor escaldante do sol acompanhei sua intervenção na Galeria a Céu aberto, na escadaria da João Manoel, no bairro Centro Histórico de Porto Alegre/RS. Não estava sozinho. Me chamaram a atenção seus desenhos em formas de abelha. Ao mesmo tempo que o artista urbano intervinha fazia um salchipão (como é conhecido o pão com salsichão em Porto Alegre) em uma pequena churrasqueira improvisada ao lado do muro. Dividindo sua atenção entre a pintura e a conversa comigo, falou-me sobre como tinha aprendido a pintar.

Este acompanhar dos gestos de artistas urbanos implica um estar junto "de perto e de dentro" (Magnani, 2002) nos seus momentos de intervenção. Se artistas urbanos são praticantes da urbe, a etnografia pode contribuir muito para os estudos de arte, imagem e cidade quando mostra uma versão particular das dinâmicas de como a cidade é praticada. Assim, por etnografia das gestualidades entendo o acompanhamento etnográfico de momentos ligados a "medialidade" (Agamben, 2018) do processo artístico de artistas urbanos. Ao descentralizarmos nossa atenção da estética final das intervenções urbanas, sem desconsiderá-las, encontramos um mundo gestual. A imaginação, a escolha de um espaço para intervenção, a escolha de materiais, a relação dos artistas com o espaço em que intervêm, todos estes são elementos que

Figuras 1 e $2 \triangleright$ Percebemos como intervenções artísticas urbanas vão além de sua estética final. As imagens fazem referência aos atos projetivos (desenho em papel) e gestuais (contato com a matéria do muro) presentes nos gestos das intervenções. As fotografias foram tiradas durante o trabalho etnográfico na Galeria a Céu aberto em Porto Alegre
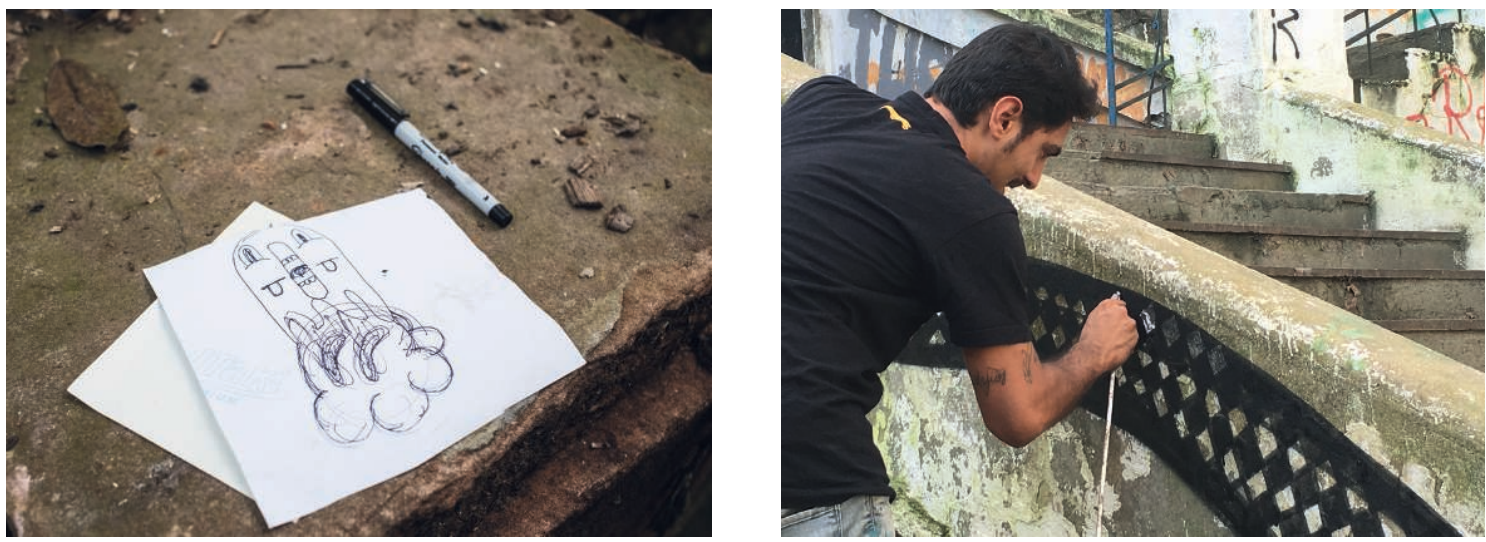

Fonte: Acervo José Luís Abalos Júnior. 
fazem parte de um contexto de produção da arte urbana que tem o espaço da rua como ateliê.

O som da agitação das latas de spray representa uma paisagem sonora corriqueira no espaço do gesto de artistas urbanos. Ao acessar o gesto pelo som, captamos a singularidade de um momento único que nos escapa, um "devaneio da vontade". Essa ideia é trazida por Gaston Bachelard em dois livros publicados, um após o outro, que fazem parte dos quatro elementos denominados "hormônios da imaginação"s. Se trata de $A$ terra e os devaneios da vontade: ensaio sobre a imaginação das forças (1991) e A terra e os devaneios do repouso: ensaio sobre as imagens da intimidade (2003).

Bachelard expõe que a matéria terrestre é provocadora de devaneios de vontade e repouso. Resumidamente, os primeiros estariam ligados aos movimentos de extroversão, que nos "obrigam a agir sobre a matéria"; e os segundos, ao movimento de introversão, no qual há uma "valorização da intimi- um processo de figuração estética e diz respeito a uma "inserção afetiva na sociedade" (Leroi-Gourhan, 2002, p. 73)

Já para Bachelard o gesto pode ser visto como um "esforço criador dos dedos sobre a matéria" (Bachelard, 1991, p. 17). O processo de figuração de uma tag, pelo pixador, de um personagem pelo grafiteiro, de um stencil e um cartaz pelo artista que utiliza intervenções que envolvem técnicas com cola, pode dizer respeito a um devaneio da vontade, um sonho de ação precisa, pois "só gostamos daquilo que imaginamos" (Bachelard, 1991, p. 18). O cuidado aqui é para que a imaginação não seja desvalorizada e vista como uma desorganização imaginária, pelo contrário, ela diz respeito a uma "projeção de tarefas organizadas" (Bachelard, 1991, p. 22). É assim que o grafiteiro vence o muro trabalhando, pois o trabalho na matéria é uma "beleza prometida" (Bachelard, 1991, p. 33).

Figuras 3, 4 e $5 \triangleright O$ artista urbano Keith Haring pinta o muro de uma estação de metrô em Nova Iorque
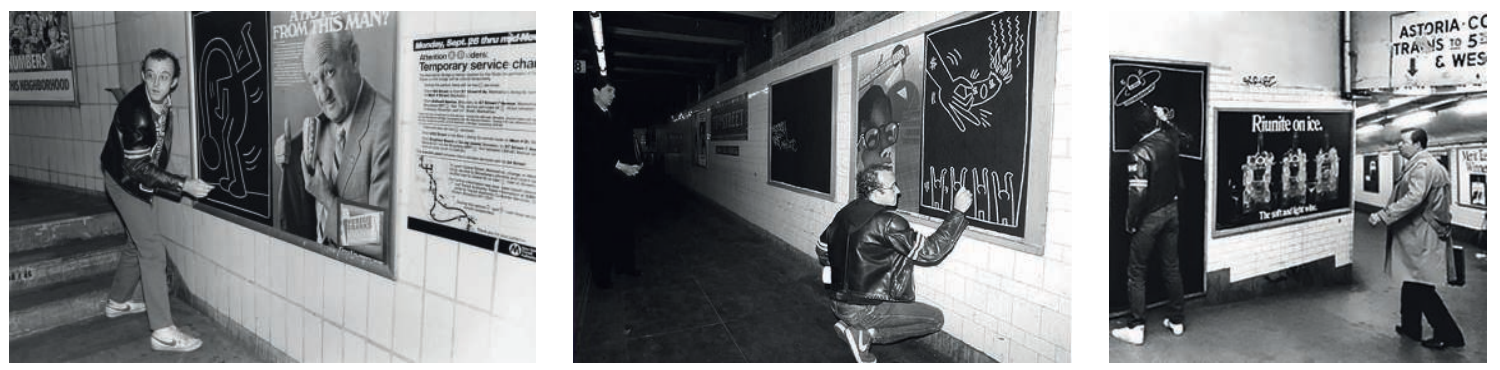

Fonte: https://www.widewalls.ch/keith-haring-artwork/

dade material". Estes gestos, estruturados em uma dialética do trabalho da imaginação da matéria, podem dizer muito sobre as práticas de grafiteiros nas cidades, desde que percebamos os sinais de suas imaginações criadoras através de uma aventura etnográfica pela urbe por vezes sintetizada aqui na Etnografia de Rua (Eckert \& Rocha, 2013).

O gesto do grafiteiro de vencer a luta travada contra o muro pode ser invisibilizado por uma abordagem unicamente estética das intervenções urbanas. Partindo da linguagem dos gestos (Leroi-Gourhan, 2002), podemos entender o graffiti como um "desabrochar da forma", na qual a estética final desta intervenção é somente, e nem por isso menos importante, uma parte do processo das artes urbanas. Para Leroi-Gourhan, a perspectiva do trabalho criativo é sempre significar. Assim, estamos encarando um comportamento figurativo que tem como instrumento os sentidos e a "capacidade de extrair da realidade elementos que permitam reconstruir uma imagem simbólica da mesma" (Leroi-Gourhan, 2002, p. 180). O autor nos refere que o gesto gera

\section{O gesto enquanto rítmica, técnica e geração}

A tradição gestual de artistas urbanos envolve o aprendizado de capacidades técnicas como o uso do spray, de colas mais ou menos aderentes, etc. Sobre a historicidade do spray é interessante relatar que a partir da década de noventa surgiram os primeiros sprays voltados exclusivamente para arte urbana ${ }^{6}$. Este nicho de mercado percebeu um meio lucrativo para além dos sprays de pintura automotiva. Desde então algumas microrrevoluções técnicas chegaram ao dia a dia de artistas urbanos como o "bico fino". Através de uma saída mais controlada da tinta da lata, foi possível fazer contornos mais exatos, o que fomentou uma maior possibilidade de criação de personagens e uma rota de desvio do graffiti tradicional?.

Tendo esse cenário em vista, uma pequena mudança técnica na forma de segurar ou apertar a lata de spray associa-se a um incentivo às transformações estéticas que dividem o graffiti das suas variações posteriores, como a da street art. Agamben 
relaciona a perda de controle sobre uma tradição gestual a uma "patologia do gesto", do qual salienta uma preocupação muito pessoal com a perda da humanidade em dominar seus gestos (Agamben, 2018 , p. 2). Podemos nos perguntar: tecnicamente e gestualmente, o que durou entre distintas gerações de artistas urbanos? Há diferenças significativas entre as formas gestuais de artistas urbanos tradicionais, que se iniciaram a pintar nas ruas a partir da década de oitenta, e artistas urbanos contemporâneos que tiveram o início de sua prática após a popularização de dispositivos técnicos e de internet ${ }^{8}$ ?

O dilema entre a manutenção de uma tradição gestual e uma liberdade técnica nas gestualidades do uso de equipamentos está presente no campo cultural do graffiti. Tal dilema materializa-se em conflitos geracionais narrados por diversos artistas urbanos com que pude conversar na cidade de Porto Alegre. Marcelo Pax, um destes artistas de rua, relata as distinções presentes nas relações intergeracionais de grafiteiros.

Figura $6 \triangleright$ O documentário Style Wars, dirigido por Tony Silver e produzido em colaboração com Henry Chalfant, é uma boa referência para pensarmos as gestualidades tradicionais do graffiti de inspiração nova-iorquina

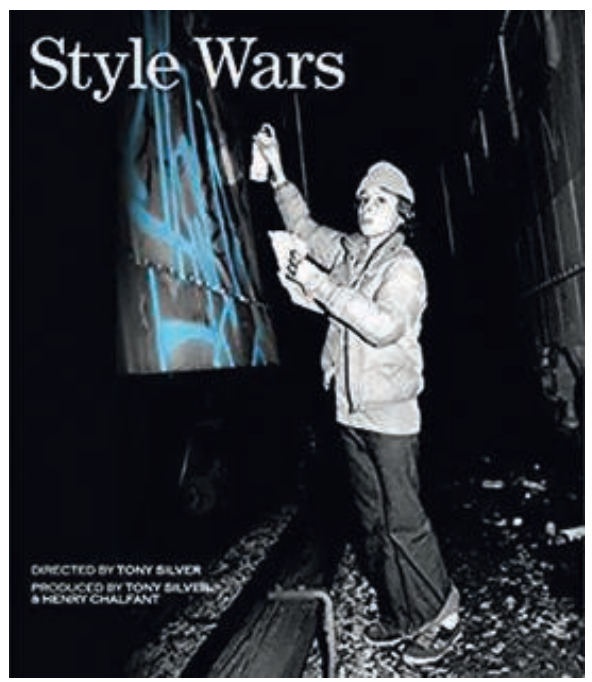

Fonte: http://www.stylewars.com

Hoje a informação é muito fácil para os grafiteiros novos, tudo chega de mão beijada, muito fácil pra eles. Então esses novos grafiteiros não dão o mesmo valor que a gente dava antigamente pra informação. Tipo de tu receber um bico de spray e tu limpar aquilo com solvente por que é o único que tu tem. Claro que hoje em dia tu não precisa fazer por que o acesso é muito mais fácil. $\mathrm{E}$ ao mesmo tempo junto com isso se perde um pouco do respeito também que é uma característica forte do graffiti.

A artificação ${ }^{9}$, a comercialização e o surgimento de novos coletivos de arte urbana fazem parte de um contexto mais geral que marca as diferenças gestuais e geracionais entre artistas urbanos. A ilegalidade da prática, como podemos ver no olhar atento de Keith Haring presente nas imagens acima, se mantém até hoje nas dinâmicas da rua. $O$ trabalho comercializado, como o advento do novo muralismo urbano (Abarca, 2016), impactou não só a estética das artes nas cidades, mas também as gestualidades de quem as produz. Contudo, estar em um nível de produção comercializado não exclui a possibilidade de $o$ artista estar concomitantemente fluindo entre práticas legais e ilegais, como diz Jota Pê:

O grafite não tem muita definição, não tem muita regra pra gente definir. O grafite é na rua. A inspiração que eu tenho de pintar e fazer trabalhos comerciais, parcerias, é fruto da técnica que aprendi na rua... Eu vejo que tem esses lados, o grafite subversivo continua, faço meu personagem, mas também vou fazer umas letras, vou mudar de nome para as pessoas não saberem quem sou, vou inventar um nome na hora, e é isso aí. Não tem muito pra onde ir, na verdade. É técnica. É a gente sair domingo para ao invés de estar vendo TV, estar pintando. E o trabalho é trabalho, eu acho que a gente herda essa técnica boa das ruas, rapidez, agilidade, pra isso eu uso spray. Eu consigo fazer algo subversivo e comercial ao mesmo tempo.

No debate sobre o que é o graffiti aqui ele é narrado como uma técnica, como algo aprendido nas ruas, e que, independente da manutenção de uma identidade marcada pela prática ilegal, há uma essencial gestual ligada ao aprendizado de um saber fazer que permeia a práxis de artistas urbanos.

O trabalho na matéria terrestre é algo intrínseco a quem intervém na cidade. Os ritmos destas intervenções são outro ponto importante a se referir, pois as diferentes técnicas e modalidades de expressões urbanas dizem respeito a ritmos variados de relação com o espaço-tempo (Diógenes, 2017). A pixação e a adesivagem (Stickers Art), por exemplo, se associam a espaço-tempo curto, diminuído pela dinâmica do fazer artístico de quem se propõe a intervir. Já em operações como a do graffiti, na qual a criação de personagens pode ser algo inerente, a relação com o espaço-tempo é diferenciada. Assim podemos perceber o ritmo como algo criador de formas na cidade, pois as marcas no mundo material "só existem como vividas na medida em que tenham materializado num invólucro rítmico" (Leroi-Gourhan, 2002, p. 115). 
Figuras 7 e $8 \triangleright 0$ pixador Toniolo intervém na cidade de Porto Alegre desde o início da década de oitenta até os dias atuais
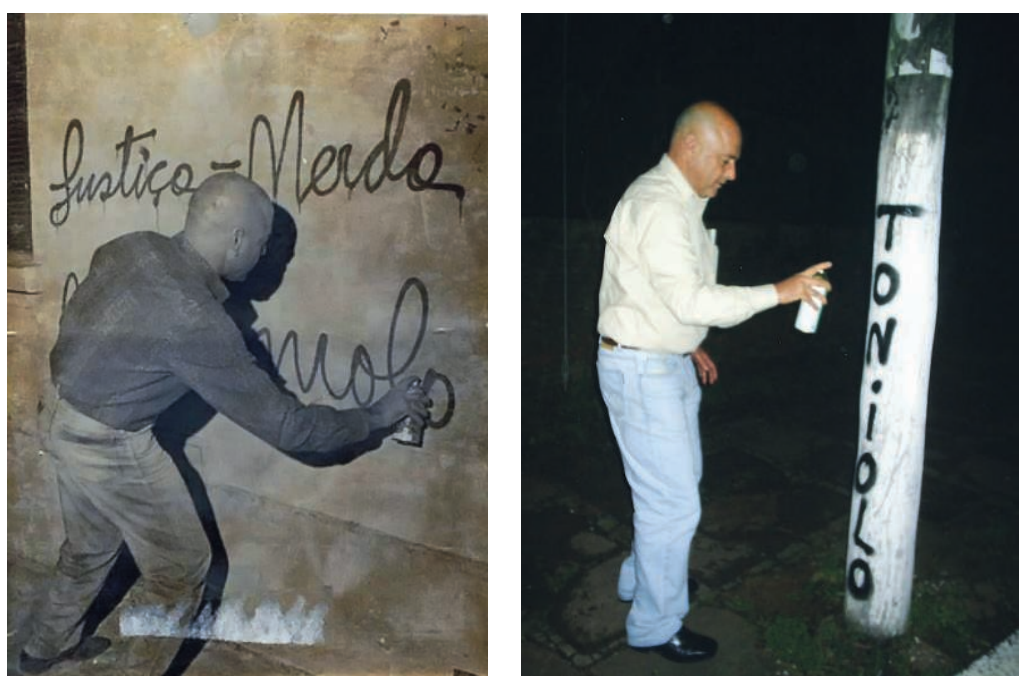

Fonte: Acervo do artista.

\section{O gesto enquanto política ontológica}

Por definição, uma intervenção artística urbana exige um sujeito que imagine, operacionalize, gestualize. O gesto é o processo artístico invisibilizado que torna possível uma estética final. Agamben cita Quintiliano, que escreve sobre "mãos que falam", representantes dos gestos de artistas urbanos que garantem a vida da arte pública na cidade.

Agamben vê o gesto não como um meio presente no processo artístico, mas como uma expressão de "medialidade". Diz o autor que "o gesto não é nem um meio, nem um fim: antes, é a exibição de uma pura medialidade, o tornar visível um meio enquanto tal, em sua emancipação de toda a finalidade" (Agamben, 2018, p. 03). Aqui, a medialidade é a dimensão em que se projeta, em que se sonha, em que se devaneia contra as provocações insaturadas pela matéria. Desta forma a compreensão dos gestos passa pela compreensão dos seus ritmos, dos momentos de suspensão do processo artístico, de interrupção, que questionam a ideia de que "todo gesto é movimento" (Agamben, 2018, p. 03). Ao pensar nos estatutos das pausas e dos movimentos (o apertar do bico do spray ou descolar do papel adesivo), se vê com incomparável clareza que o gesto não é somente o movimento corpóreo do artista de rua, mas também sua interrupção entre dois movimentos, "a epoché que imobiliza e, ao mesmo tempo, comemora e exibe o movimento" (Agamben, 2018, p. 03).

As gestualidades de artistas urbanos influenciam e são influenciadas pelos novos aparatos técnicos que revolucionam a maneira de intervir na rua. Contudo, uma maior variedade de cores de tinta, uma maior possibilidade de realização do traço fino são conquistas da modernidade, que nem sempre chegam aos artistas urbanos, afinal, "a memória dos meninos que pintam na rua é marcada pela necessidade de tinta" (Abalos Junior, 2018b, p. 157). Se há uma revolução material e técnica que afeta este campo, há também uma historicidade de resistência técnica advinda de jovens de classes populares que não tinham (e não continuam não tendo) condições financeiras de comprar novos materiais, mas reinventavam as ferramentas a que tinham acesso, como o canetão, o spray automotivo, a criatividade nas misturas das poucas cores acessíveis, e a transfiguração de um bico fino.

As consequências gestuais destes novos artefatos que chegaram à cena da arte urbana implicaram, em maior ou menor grau, um distanciamento de uma estética inicial do graffiti como as expressões do "throw up" e do "bomb". Esse desvio não acarreta uma ruptura com o graffiti tradicional, principalmente o de referência nova-iorquina, mas sim continuidades e descontinuidades advindas de um avanço tecnológico das ferramentas técnicas de produção de arte urbana. Nota-se uma massiva produção de personagens urbanos feitos com a precisão técnica que as ferramentas modernas permitem; entretanto, isso não elimina a duração e a permanência de produções de intervenções clássicas do graffiti ${ }^{10}$.

Figura $9 \triangleright$ Um exemplo de throw up clássico, feito rapidamente e com pouca variabilidade de tintas, na cidade de Nova Iorque

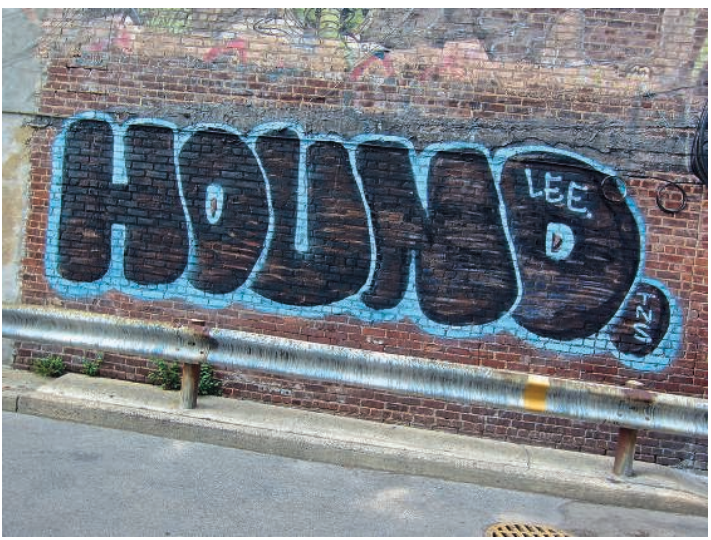

Fonte: hiveminer.com 
Todas estas questões nos levam a perceber uma arte urbana que vai "além do muro" (Leal, 2017) e do que chega ao nosso campo de visualidade na cidade. Neste sentido, mostrar o gesto é mostrar algo no meio do seu aparecer, sem o reducionismo estético do seu aparecimento. Mas intervenções artísticas urbanas podem ser algo feito sem preocupação com sua estética final? Agamben refere que "o que o teólogo não pode aceitar é que existam atos humanos realizados todos os dias que não se deixam, em caso algum, inscrever no dispositivo das vontades e dos fins". Esta forma de pensar na medialidade gestual da arte urbana não significa o desmerecimento da relevância dada à sua estética final, mas o pensar nos processos gestuais por vezes inviabilizados na análise sociológica.

Ao buscarmos o gesto, encontramos o ainda não-figurado, o que está em processo. O que representa apenas uma forma abstrata daquilo que realmente contém. E é isto que Agamben nos desafia a pensar quando aborda uma "consistência ontológica dos gestos": o momento de uma educação atenta e uma paciência etnográfica para o conhecimento de algo que ainda está por vir. Em síntese, "no gesto não se conhece algo, mas apenas sua cognoscibilidade" (Agamben, 2018, p. 03).

\section{O gesto enquanto fluxo de vida}

O gesto, além de movimento, é um lugar onde vários aconteceres se entrelaçam. O acontecer dos dedos com bico do spray representa um procedimento técnico presente em um saber-fazer adquirido em um campo cultural. O acontecer da tinta com a matéria da cidade, plana, rugosa, de difícil ou fácil absorção. O acontecer da adrenalina presente no contexto de ilegalidade do ato. Nesse sentido, sentimentos, coisas e corpos se articulam em um "parlamento de fios" (Ingold, 2012) ou, como denominei neste subtítulo, em um fluxo de vida.

Questionando a teoria do ator-rede (Latour, 2012) que estabelece a noção de objeto e rede como centrais, Tim Ingold (2012) propõe uma retomada das noções de fluxos de vida. O autor nos ajuda a entender a estética final de uma intervenção artística urbana não como um "objeto", mas como uma "coisa" permeada por fluxos vitais e integrada nos ciclos e dinâmicas da vida na cidade. Isso é evidenciado quando o autor se posiciona em prol de uma "ontologia que dê primazia aos processos de formação ao invés do produto final, e aos fluxos e transformações dos materiais ao invés dos estudos da matéria" (Ingold, 2012, p. 26).

Para articular uma perspectiva teórica que verse sobre o tema do gesto a uma etnografia que busque o acompanhamento de gestualidades de artistas urbanos, caminhei com o artista Marcus Gorga pelas ruas de Porto Alegre. O artista fabrica adesivos, ou sticker arts, na sua casa através da técnica de serigrafia. Produz suas telas com as imagens de macacos há alguns anos, desde que adotou este personagem como um ícone da sua produção visual. Após produzir uma quantidade considerável de adesivos, caminha pela cidade espalhando-os em pontos que, para si, são estratégicos. Uma forma de (co)produzir regimes visuais na urbe marcada por pequenos gestos. Segundo o artista, os meios de produção do graffiti e dos sticker arts ${ }^{11}$ são parecidos, pois são feitos na cidade, mas diferem nas suas lógicas e temporalidades ${ }^{12}$.

Graffiti e sticker art são artes parecidas porque elas vão aparecer na rua, no ambiente público. São artes irmãs porque se comunicam. No Brasil muita gente inicia com a pichação, eu comecei com os adesivos. Eles vieram antes do graffiti. Diferente do graffiti que tu demora e só consegue fazer um por dia, o adesivo tu consegues fazer em grandes quantidades. No início eu fazia meus próprios adesivos a mão, depois descobri a serigrafia que pude fazer e colar muitos por dia. Mesmo sendo na e para a cidade, o graffiti e sticker art são um pouco diferentes, envolvem técnicas e tempos diferentes.

Marcus Gorga, como um artista experiente, ao caminhar olha para os lados. Observa buracos vazios nas superfícies. As placas de trânsito, que possuem mais de dois metros de altura, parecem ser um ideal de alcance. Lá já estão muitos outros adesivos colados por sujeitos que talvez o artista conheça. Após visualizar o alvo, prepara-se o adesivo. Há uma capacidade de destacar o papel com cola de seu papel base (eu mesmo tive algumas dificuldades em fazê-lo quando tentei ajudar). Depois disso há o grande momento da intervenção. Parece não haver mais espaços possíveis entre os stickers arts presentes nas costas da placa de trânsito desejada. O artista, mesmo que seja alto, é obrigado a levantar a ponta dos pés e dar um pequeno salto para atingir sua finalidade. Com o adesivo em mãos, o artista necessita de força no momento da colagem, certificando-se de que sua arte não caia e desapareça tão cedo. Após o ato, ele sorri ao ver uma agradável composição de pequenos adesivos na qual o seu é um novo integrante. Novas placas e muros virão na próxima esquina.

Quando acompanhamos artistas urbanos pela cidade, é perceptível uma "educação da atenção" vinculada a um conhecimento prático de uma cidade praticada (De Certeau, 2003). Se "habitar o mundo é se juntar ao seu processo de formação" (Ingold, 2012, p. 31), praticar uma etnografia que leve em conta as gestualidades de artistas urbanos significa coabitar estas intervenções. Ou seja, habitar a urbe 
Figuras 10, 11 e $12 \triangleright$ A demonstração de uma gestualidade presente nas práticas de intervenções artísticas urbanas
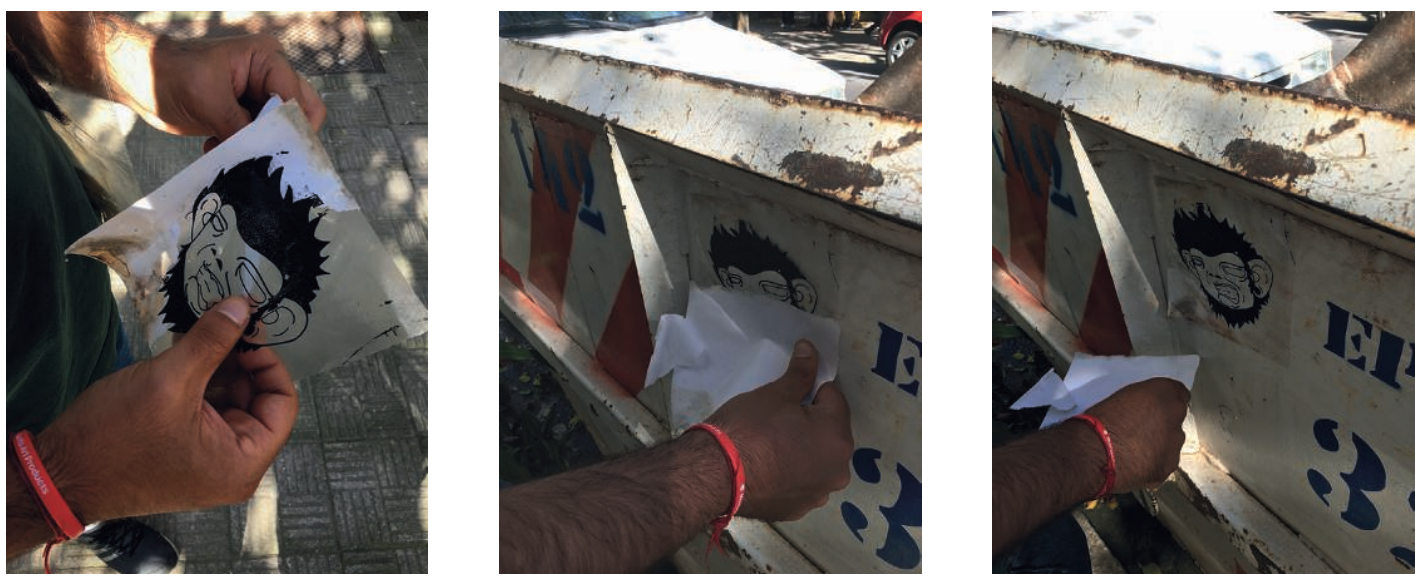

Fonte: Acervo de pesquisa José Luís Abalos Júnior.

conjuntamente com estas e estes personagens, focos de um procedimento etnográfico que preze os processos presentes no que vemos estampado na cidade. A curiosidade etnográfica aqui é um saber onde habita o sujeito que intervém na cidade através da sua própria obra.

No caso de Gorga, seu personagem se relaciona com a busca de um estilo próprio, buscando referências em outros artistas urbanos, na internet - que ainda estava sendo popularizada no início dos anos $2000^{13}$ - e em uma diversidade de materiais que continham gravuras, desenhos, que poderiam servir como fonte de inspiração.

Eu sempre tive de vontade de fazer uma coisa minha. Buscava referências na internet, que ainda estava começando no início dos anos 2000, com os amigos, etc. Um dia eu estava folhando um livro de biologia e tinha a imagem de um macaco e fiquei me perguntando: porque não um macaco? O meu primeiro macaco foi um macaco fazendo um sinal de legal, positivo. Eu comecei a fazer ele na rua e foi uma identidade visual que eu tinha. O fato de o macaco urbano ser verde é importante também, porque eu tenho uma relação à natureza e expresso isso na arte de rua. Então eu me vejo muito na minha arte, e acho que ela também diz muito sobre mim.

Gorga e a produção de Macacos Urbanos são um bom exemplo para pensarmos nas relações entre arte e cidade, e, mais que isso, humanizá-las. Refletir sobre o gesto é reconhecer um fluxo de vida presente nas cores das metrópoles. Quando o artista encara o muro como mais uma dimensão possível do seu trabalho, lidando com a fronteira entre privado e público, legal e ilegal, há um saber técnico, político e gestual ali integrado.
Figura $13 \triangleright$ O primeiro macaco desenhado por Gorga em papel no início dos anos 2000. Mais tarde o artista viria a reproduzir o desenho nos muros da cidade

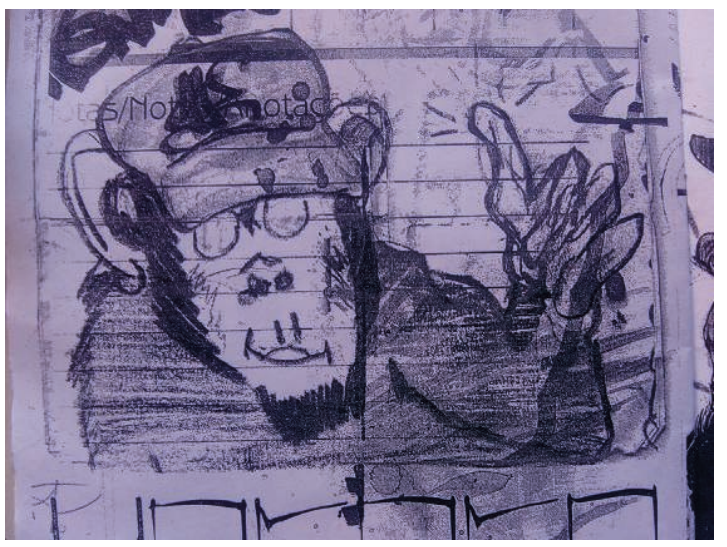

Fonte: Acervo do artista.

A ideia de "trazer as coisas de volta à vida" (Ingold, 2012) pode ser traduzida aqui como trazer os gestos de volta às intervenções urbanas na cidade. É um pensar na dimensão ontológica e no propósito operacional do gesto enquanto algo integrante das artes urbanas. No fim, é a obsessão da análise estética de intervenções artísticas urbanas que tem sepultado a dimensão das suas gestualidades. Não se trata de extinguir a análise estética final, a preocupação aqui trazida, antes de tudo, diz respeito a uma "atenção generosa" (Ingold, 2016, p. 405) com as gestualidades.

\section{Conclusão}

Durante o texto procurei demonstrar o que é o gesto e as implicações da técnica, na visão de alguns autores da escola francesa, mais especifi- 
camente da fenomenologia da experiência, como Leroi-Gourhan (2002) e Bachelard (1993). Também recorri a Agamben (2018), para falar de uma ontologia e uma política dos gestos. Por fim, trouxe a perspectiva ecológica de Ingold (2010; 2012; 2016), relacionando-a com a dimensão dos gestos. Associei estes campos teóricos com o cenário emergente da arte urbana, que, assim como ocupa o espaço visual da cidade, vem ocupando a reflexão de muitos pesquisadores (Campos, 2017a).

Por etnografia da gestualidade entendo o acompanhamento etnográfico de momentos ligados à medialidade do processo artístico de artistas urbanos. Sem desvalorizar a importância da estética final de suas expressões, encontramos aqui um mundo rico de significados nas performances, nas técnicas e no saber-fazer de quem intervém na cidade. Uma etnografia atenta a estes cenários advém de um trabalho de campo paciente, produto de uma educação da atenção (Ingold, 2012) associado a etnografia de rua (Eckert \& Rocha, 2013).

Procurei ver a estética final de intervenções artísticas urbanas não como um objeto, mas como uma forma perpassada por fluxos vitais integrada às dinâmicas da cidade. Uma etnografia de gestualidades das artes urbanas estranha o imponderável analítico estético do que vemos estampado na cidade. Se preocupa com uma "catalogação" e um "mapeamento" de expressões urbanas em grandes capitais do mundo. Hoje muitas cidades fomentam e pensam suas artes articuladas nas políticas de turismo (Campos, 2017b). É como se pudéssemos "desligar" intervenções artísticas urbanas de seus gestos. Como se elas estivessem na cidade, prontas para serem cadastradas, e seus gestos em outro lugar.

Relacionando o campo das gestualidades ao da produção visual, percebemos a capacidade de hipermidiatização dos gestos. A produção imagética como forma de escrita ajuda o antropólogo urbano a (re)pensar as formas de produção de conheci- mento na e sobre a cidade. A fotografia, o vídeo, o desenho, etc., são meios de criação de saberes acolhedores que nos aproximam sensivelmente dos gestos e nos auxiliam no entendimento de como a cidade, e a arte urbana, é praticada na cotidianidade da vida na urbe.

Por fim, a figura 14 ao final desse texto, produzida pela artista urbana Thay Petit, representa os processos que envolvem uma intervenção urbana e nos desafia a pensar como a imaginação e os gestos compõem, e fazem parte, do processo artístico de quem se expressa visualmente na cidade. É em Rancière (2005) que encontramos o tema da escrita conceituado enquanto "partilha do sensível". Talvez esta seja uma primeira pista para pensarmos as dimensões de uma "virada gestual" nas pesquisas sobre intervenções artísticas urbanas: a partilha de uma tag, de um personagem urbano, de um cartaz à base de cola, é também uma partilha de afetos e sensibilidades.

\section{Notas}

\footnotetext{
1 Agamben lembra o Dicionário de Língua Latina, de Varrão, que distingue três graus de atividade humana "Facere, Agere e Gerare".

2 Há muitas questões ligadas a dimensão de gênero, embranquecimento e enobrecimento no tema das intervenções artísticas urbanas. Mesmo estes marcadores sociais da diferença não sendo o foco desta produção, este é um tema constantemente acionado. Se há transformações na cultura do graffiti nos dias atuais, parte delas certamente passam pela inclusão de mulheres, brancos e jovens de classe média nesse meio como produtoras e produtores de muitas intervenções.

${ }^{3}$ Coleções etnográficas advêm do "método da convergência", que é a base para o processo de classificação estrutural dos símbolos, que consiste em "um método tanto pragmático quanto relativista de observar a convergência de vastas constelações de imagens, mais ou menos estáveis e regulares, estruturadas por certo isomorfismo de símbolos". (Durand, 1984, p. 33).
}

Figura $14 \downarrow$ Thay Petit demonstra através desta ilustração os processos pelos quais a arte urbana pode passar: a inclusão do ato imaginativo e gestual junto à referência estética final

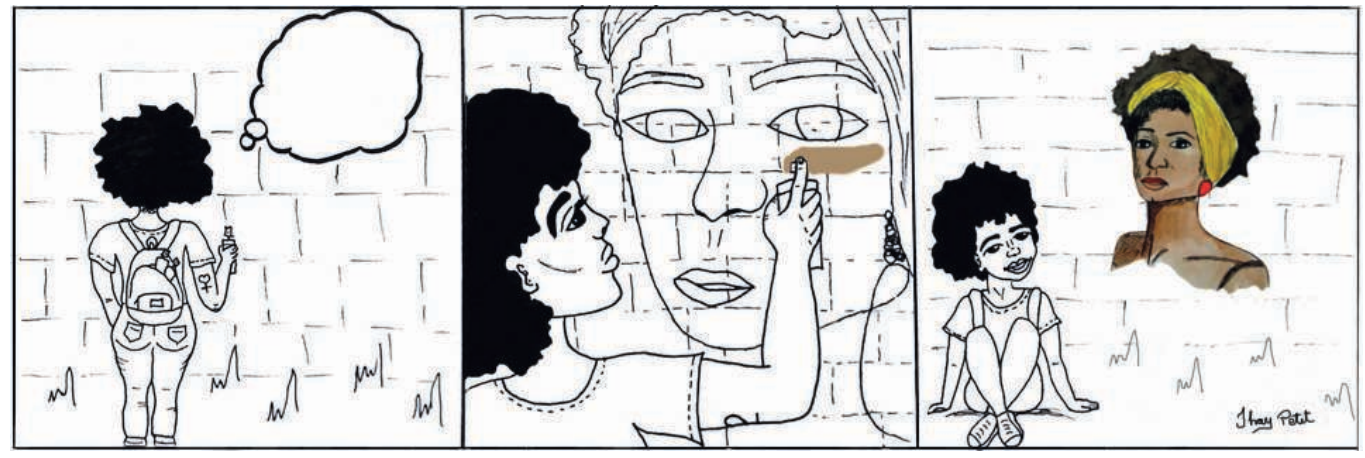

Fonte: Acervo da artista. 
4 O "bomb" é uma forma de graffiti clássico e rápido, feito com letras gordas, vivas e mais simples. No Bomb são utilizadas duas ou três cores de tinta, uma para preencher a letra e as outras para contornar e fazer alguns detalhes.

5 Gaston Bachelard (1993) fundamenta-se em um sentimento humano primitivo formado a partir de interesses orgânicos primordiais, chamados de "hormônios da imaginação"- a água, o ar, a terra e o fogo, que caracterizam a imaginação material e dinâmica, faculdade ontogênica, responsável pela gestação simultânea do homem e do mundo.

6 "Esprais de pintura per a grafiters de tot el món" em https://www.leconomic.cat/article/708333-esprais-de-pintura-per-a-grafiters-de-tot-el-mon.html

7 Quando me refiro ao graffiti tradicional, faço uma associação com uma tradição surgida em Nova Iorque como um elemento do hip hop. Esse modelo globalizou-se, sendo incorporado, de diversas formas, às dinâmicas de muitas metrópoles do mundo. Contudo, essa não é a única referência de intervenção urbana clássica. Na década de setenta, há tradições de intervenção que surgem na Europa e na América Latina, não necessariamente ligadas a raiz nova-iorquina: como as do muralismo político e do Maio de 68, em Paris, e a do muralismo mexicano. (Ferro, 2011)

8 Conforme Ricardo Campos (2012), a pixelização tem produzido uma transformação nas práticas e modos de fazer da arte urbana. Este conceito é importante para pensar não só como infraestruturas e tendência globais do graffiti mundial agem nas cidades, mas também como artistas urbanos reagem, modificam ou reproduzem estas implicações.

9 O conceito de artificação (Shapiro, 2007; Shapiro \& Heinich, 2013) leva em consideração os vários componentes e dinâmicas envolvidos na transição da não-arte para a arte. Essa transformação consiste em um processo social complexo da transfiguração das pessoas, das coisas e das práticas.

${ }^{10} \mathrm{Em}$ muitas das entrevistas que realizei com artistas urbanos, surgiu uma narrativa na qual o graffiti "moderno" e o "clássico" não se excluem ou contrapoem. Ou seja, o artista que faz um trabalho demorado, financiado, com um ímpeto técnico na produção de forma significativa, é o mesmo que pode continuar a produzir as mesmas intervenções clássicas que nos remetem aos primórdios do graffiti americano.

${ }_{11}$ Assim como o stencil, o adesivo, ou stiker art, é uma das modalidades do chamado pós-graffiti (Dickens, 2009), ou do que pode ser chamado mais genericamente de Street Art (Soares Neves, 2015), caracterizado por ser um novo movimento dentro do graffiti que usa materiais menores à base de cola. Diferente de outros tipos de intervenções, igualmente ilegais, a sticker art pode ser realizada durante o dia; entre outros motivos, pela sua facilidade de acesso a materiais e pela rapidez na sua produção e no momento de intervenção. Não há uma posição definida para onde colocar os stickers, nem como alcançar lugares altos, por mais que haja um roteiro flexível associado a circuitos (Magnani, 2002) de arte urbana.

12 A ideia de Educação da Atenção trazida por Ingold (2010) nos ajuda a pensar o quanto sujeitos que intervêm na cidade, na sua maioria desde muito novos, produzem uma capacidade de percepção de onde, quando e como intervir. Ao caminhar com Marcus Gorga, artista que além de graffiti também produz sticker art, percebi o quanto essa atenção educada para placas, muros, lixeiras, casas abandonadas diz muito sobre os gestos destes habitantes da urbe. Assim, a adesivagem urbana é um bom exemplo de como a estética final do que acessamos visualmente enquanto intervenção na cidade faz parte de um mundo material.

13 Abordo mais o impacto da internet no campo da arte urbana em outro texto denominado "De onde vem os desenhos da cidade? Eu, o fotolog e os monstros dentuços" (Abalos Junior, 2018a), no qual refiro a importância que tiveram plataformas como o Fotolog na formação, identidade e globalização da arte urbana brasileira.

\section{Referências bibliográficas}

Abalos Junior, J. L. (2018a). De onde vem os desenhos na cidade? Eu, o Fotolog e os monstros dentuços. PIXO - Revista de Arquitetura, Cidade e Contemporaneidade, 2, 36-49.

Abalos Junior, J. L. (2018b). Quem sujou as mãos de tinta? Estética, gesto e matéria em intervenções artísticas urbanas. Vista - Revista de Cultura Visual, 3, 148-171.

Abarca, J. (2016). From street art to murals, what have we lost? Street Art \& Urban Creativity Scientific Journal, 2(2), 60-67.

Agamben, G. (2008). Notas sobre o gesto. ArteFilosofia, 4, 09-14.

Agamben, G. (2018). Por uma ontologia e uma política do gesto. Chão da Feira: Caderno de Leituras - Série Intempestiva, 76. Retirado de https://chaodafeira. com/wp-content/uploads/2018/04/cad76ok.pdf

Bachelard, G. (1991). A terra e os devaneios da vontade. São Paulo: Martins Fontes.

Bachelard, G. (1993). A poética do espaço. São Paulo: Martins Fontes.

Bachelard, G. (2003). A terra e os devaneios do repouso: ensaio sobre as imagens da intimidade (2. a Edição). São Paulo: Martins Fontes.

Campos, R. (2012). A pixelização dos muros: graffiti urbano, tecnologias digitais e cultura visual contemporânea. Revista Famecos: mídia, cultura e tecnologia, 19(2), 543-566.

Campos, R. (2010). Porque pintamos a cidade? Uma abordagem etnográfica do graffitte urbano. Lisboa: Fim de Século.

Campos, R. (2017a). O espaço e o tempo do graffiti e da street art. Cidades, Comunidades e Territórios, $34,1-16$.

Campos, R. (2017b). Arte urbana enquanto património das cidades. Lisboa: CICS.NOVA - NOVA FCSH.

De Certeau, M. (2003). A invenção do cotidiano 1 - Artes de fazer (9. a ed.). Petrópolis: Vozes.

Dickens, L. (2009). The geographies of post-graffiti: art worlds, cultural economy and the city (tese de doutoramento). Londres: Royal Holloway University of London. 
Diógenes, G \& Chagas, J. (2016). O ruidoso silêncio da pixação: linguagens e artes de rua. NAVA, $1(2), 304-330$.

Diógenes, G. (2015). A arte urbana entre ambientes: "dobras" entre a cidade "material" e o ciberespaço. Etnográfica, 19, 537-556.

Diógenes, G. (2017). Arte, Pixo e Política: dissenso, dessemelhança e desentendimento. Vazantes, $1(2), 115-134$.

Durand, G. (1984). As estruturas antropológicas do imaginário. São Paulo: Martins Fontes.

Durand, G. (1992). L'imagination symbolique. Paris: Presses Universitaires de France (PUF).

Eckert, C., \& Rocha, A. (2002). Etnografia na rua e câmera na mão. Studium, 8, 11-22.

Eckert, C., \& Rocha, A. (2008). Etnografia: saberes e práticas. In C. R. J. Pinto \& C. A. B. Guazzelli (Orgs.). Ciências Humanas: pesquisa e método (pp. 53-67). Porto Alegre: Universidade Feredal do Rio Grande do Sul.

Eckert, C., \& Rocha, A. (2013). Etnografia de rua: estudos de antropologia urbana. Porto Alegre: Editora da UFRGS.

Ferro, L. (2011). Da rua para o mundo: configurações do graffiti e do parkour e campos de possibilidades urbanas (tese de doutoramente em Antropologia Urbana). Lisboa: Instituto Universitário de Lisboa.

Ingold, T. (2010). Da transmissão de representações à educação da atenção. Educação, 33(1), 6-25.
Ingold, T. (2012). Trazendo as coisas de volta à vida: emaranhados criativos num mundo de materiais. Horizontes Antropológicos, 18(37), 25-44.

Ingold, T. (2016). Chega de etnografia! A educação da atenção como propósito da antropologia. Educação, 39(3), 404-411.

Latour, B. (2012). Reagregando o social: uma introdução à Teoria do Ator-Rede. Salvador: Editora da Universidade Federal da Bahia.

Leal, G. (2017). Graffiti para além dos muros: Usos da rua e práticas de enfrentamento da cidade. Enfoques, 16(1), 32-44.

Leroi-Gourhan, A. (2002). O Gesto e a Palavra 2 Memória e Ritmos. Lisboa: Edições 70.

Magnani, J.G.C. (2002). De perto e de dentro: notas para uma etnografia urbana. Revista Brasileira de Ciências Sociais, 17(49), 11-29.

Rancière, J. (2005). Estética e política - A partilha do sensível. São Paulo: Editora 34.

Shapiro, R. (2007). Que é artificação?. Sociedade e Estado, 22(1), 135-151.

Shapiro, R., \& Heinich, N. (2013). Quando há Artificação?. Sociedade e Estado, 28(1), 14-28.

Soares Neves, P. (2015). Significado de Arte Urbana Lisboa 2008-2014. Convocarte: Revista de Ciências da Arte, 1, 121-134.

Velho, G. (2013). Um antropólogo na cidade: ensaios de antropologia urbana. Rio de Janeiro: Zahar.

Recebido a 24/04/2019. Aceite para publicação a 05/09/2019

José Luís Abalos Júnior (abalosjunior@gmail.com). Universidade Federal do Rio Grande do Sul (UFRGS) / Instituto de Filosofia e Ciências Humanas (IFCH) / Programa de Pós-Graduação em Antropologia Social (PPGAS). 